Interrogation: hard for psychologists to act as whistleblowers

SIR - I was disappointed in your Editorial 'Responsible interrogation' (Nature 459, 300; 2009). You accept the role of psychologists in secret interrogations because they can supposedly act as whistleblowers against inhumane treatment. But your argument ignores nearly fifty years of psychology research, beginning with the classic work of Stanley Milgram (see, for example, J. Abnorm. Soc. Psychol. $67,371-378 ; 1963)$, showing that isolated individuals - including, yes, even psychologists - are notoriously poor at resisting pressure from authorities to act in abusive ways.

The position you take is naive, and in adopting it you allow yourself to be 'played' by those elements in the government and the military who are most willing to commit extreme violations of human rights.

Michael R. Jackson Department of Psychology, Earlham College, 801 National Road West, Richmond, Indiana 47374, USA

e-mail: jacksmi@earlham.edu

\section{Interrogation: our professional body forbids involvement}

SIR - Your Editorial 'Responsible interrogation' (Nature 469, 300; 2009) takes a remarkably unscientific approach to the topic of psychologists' participation in national-security interrogations, in that it omits important current facts. The scale of this omission is comparable to failing to mention Helicobacter pylori in a discussion of peptic ulcers, the treatment of which was revolutionized by the discovery that most are caused by H. pylori.

Psychology's attitude to the ethics of participating in national-security interrogations was similarly revolutionized by a petition resolution passed by the American Psychological Association (APA) membership last year (see http://tinyurl.com/ lb9nd5). This has been adopted by APA's governing body under the name of 'Psychologists and unlawful detention settings with a focus on national security'.

As a result of this resolution, and contrary to the implications of your Editorial, psychologists may not participate in nationalsecurity interrogations. The resolution, which constitutes current APA policy, states: "Be it resolved that psychologists may not work in settings where persons are held outside of, or in violation of, either International Law (e.g. the UN Convention Against Torture and the Geneva Conventions) or the US Constitution (where appropriate), unless they are working directly for the persons being detained or for an independent third party working to protect human rights."

Laurel Bass Wagner Division of Psychoanalysis, American Psychological Association, 6060 N. Central Expressway, Suite 332, Dallas,

Texas 75206, USA

e-mail: Ibwagner@tx.rr.com

Readers are welcome to comment at http://tinyurl.com/mc3byy

\section{Free will: it's a normal biological property, not a gift or a mystery}

SIR - In his Essay 'Is free will an illusion?' (Nature 459, 164-165; 2009), Martin Heisenberg argues that humans must have free will because freedom of action has been demonstrated in other animals - including those as small as fruitflies and bacteria.

Heisenberg's case rests on a combination of random chance and lawfulness, escaping the classic two-horned dilemma of determinism versus
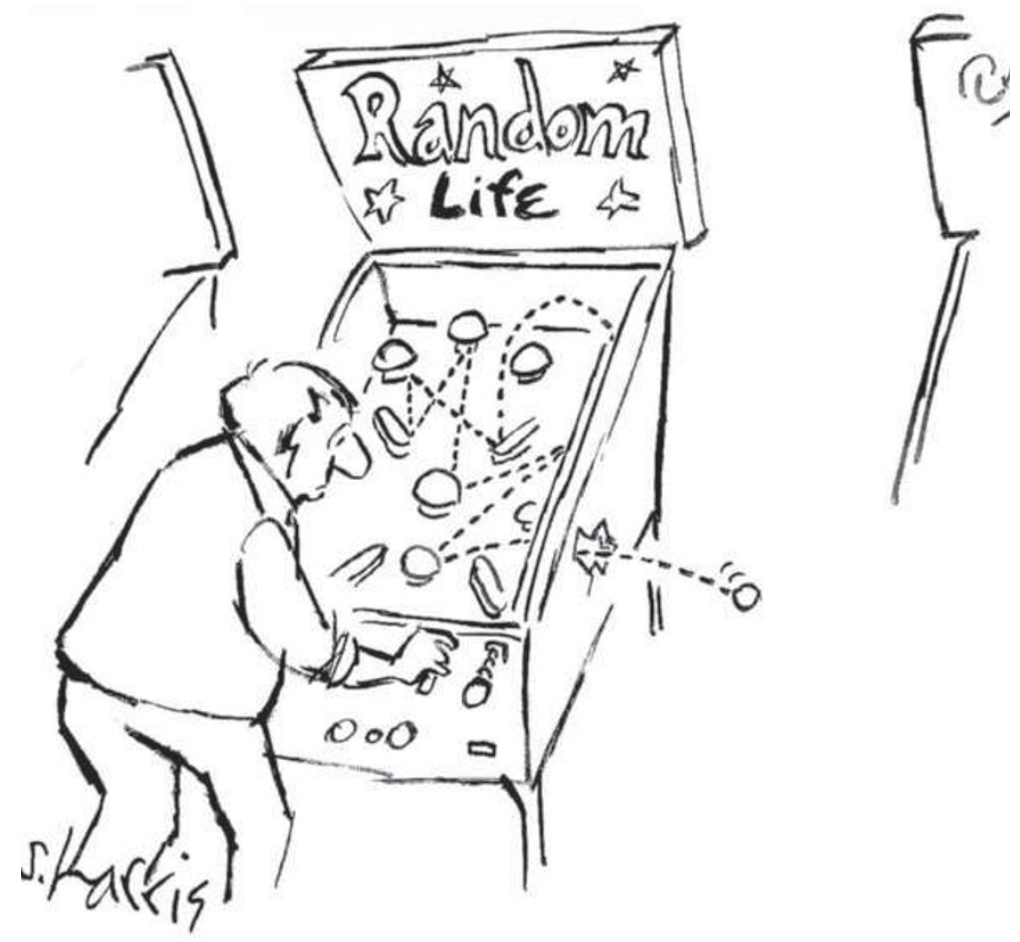

indeterminism that is so popular in introductory philosophy courses and textbooks. Starting with William James in 1884, such a two-stage combination of 'free' and then 'will' has frequently been proposed by philosophers and scientists, notably by some quantum physicists after Martin's father, Werner Heisenberg, established irreducible physical randomness with his indeterminacy principle in 1927. But academic philosophers, particularly those who work in the Anglo-American school of analytical language philosophy, have been reluctant to embrace these ideas.

The philosophers' standard argument against free will is simple and logical. If our actions are determined, we are not free.

If nature is not determined, then indeterminism is true. Indeterminism implies that our actions are random. If our actions are random, we did not will them.

Heisenberg's proposal makes freedom a normal biological property of most living things, and not a metaphysical mystery or a gift from God to humanity. The genius of this proposal is that it combines randomness with an adequate macroscopic determinism consistent with microscopic quantum mechanics.

John Locke wrote in his Essay Concerning Human Understanding, Book II, that it is not the will that is free but the man. The will determines our actions. Heisenberg writes that Kant would have been pleased. Locke too might have been pleased to see this return to common sense. We may not have metaphysical free will but we do have biophysical free will.

Robert O. Doyle Astronomy Department, Harvard University, 77 Huron Avenue, Cambridge, Massachusetts 02138, USA e-mail:bobdoyle@

informationphilosopher.com

\section{Free will: emotions and consciousness could contribute}

SIR - In his Essay 'Is free will an illusion?' (Nature 459, 164-165; 2009), Martin Heisenberg suggests that belief in free will is supported by quantum events. 